Artikel Penelitian

\title{
Correlation between Chronic Kidney Disease Severity and Cognitive Function
}

\section{Hubungan Derajat Keparahan Penyakit Ginjal Kronik dengan Fungsi Kognitif}

\author{
Epa Danisa $S^{1,2}$, Fasihah Irfani $F^{1,2}$, Aldy S. Rambe \\ ${ }^{1}$ Department of Neurology Faculty of Medicine Universitas Sumatera Utara Medan \\ ${ }^{2}$ Haji Adam Malik Central General Hospital Medan
}

\begin{abstract}
Chronic kidney disease (CKD) is an independent risk factor for cognitive impairment in all domains, especially delayed memory and executive function. The purpose of this study was to determine the correlation between chronic kidney disease severity and cognitive function. This study used a cross-sectional design in stage III, IV, and V CKD patients in the Nephrology Polyclinic of Haji Adam Malik Central General Hospital. Cognitive function tests were performed using the Montreal Cognitive Assessment (MoCA INA), digit span, and Trail Making Test A \& B. The Spearman test was used to analyze the correlation between CKD severity and cognitive function. This study involved 45 chronic kidney disease patients consisting of 28 (62.2\%) males and 17 (37.8\%) females with a mean age of $49.67 \pm 12.18$ years. The results of statistical analysis showed that there was a significant positive correlation between CKD on the MoCA-INA examination ( $r=0.618$, $p=<0.001), F D S(r=0.414, p=0.005)$, there was a significant negative correlation on the TMT A time examination ( $r=-0.425$, $p=0.004)$, TMT A error ( $r=-0.497, p=0.001)$, TMT B time $(r=-0.618, p=<0.001)$, TMT B error $(r=-0.370, p=0.012)$. The results of this study prove a significant correlation between the severity of CKD and cognitive function.
\end{abstract}

Keywords: Chronic kidney disease, cognitive function

\section{ABSTRAK}

Penyakit ginjal kronik (PGK) merupakan faktor risiko independen pada gangguan kognitif di semua domain,terutama memori tunda dan fungsi eksekutif. Tujuan penelitian ini untuk mengetahui hubungan derajat keparahan penyakit ginjal kronik dengan fungsi kognitif. Penelitian ini menggunakan desain potong lintang pada pasien PGK dengan derajat III,IV dan $\checkmark$ di Poliklinik Nefrologi RSUP.Haji Adam Malik Medan. Pemeriksaan fungsi kognitif dilakukan dengan menggunakan Montreal Cognitive Assessment (MoCA INA), digit span, Trail Making Test A \& B. Untuk menganalisa hubungan derajat keparahan PGK dengan fungsi kognitif digunakan uji Spearman. Penelitian ini melibatkan 45 pasien penyakit ginjal kronik

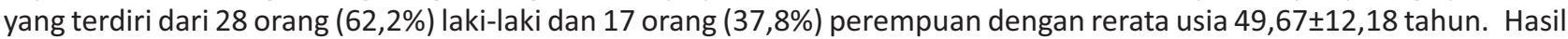
analisa statistik menunjukkan adanya korelasi positif yang signifikan antara PGK terhadap pemeriksaan MoCA-INA $(r=0,618, p=<0,001)), F D S(r=0,414, p=0,005)$, adanya korelasi negatif yang signifikan pada pemeriksaan TMT A time ( $r=-$ $0,425, p=0,004)$, TMT A error ( $r=-0,497, p=0,001)$, TMT B time $(r=-0,618, p=<0,001)$, TMT B error $(r=-0,370, p=0,012)$. Hasil penelitian ini membuktikan korelasi yang signifikan antara derajat keparahan PGK dengan fungsi kognitif.

Kata Kunci: Fungsi kognitif, penyakit ginjal kronik

Correspondence: Epa Danisa Surbakti. Department of Neurology Faculty of Medicine Universitas Sumatera Utara Medan, Jl. Dr. T. Mansur No.9, Padang Bulan, Kec. Medan Baru, Kota Medan, Sumatera Utara 20222 Tel.085262682067Email: danisaepa@yahoo.com

DOI: http://dx.doi.org/10.21776/ub.jkb.2021.031.03.2 


\section{INTRODUCTION}

Chronic Kidney Disease (CKD) is a pathophysiological process with various etiologies resulting in a progressive decline of renal function and commonly ends in renal failure. Renal failure is a clinical condition characterized by decreased kidney function, which, to some degree, requires dialysis therapy or a kidney transplant (1). High incidence of cognitive impairment and dementia has been reported in numerous studies in CKD patients, particularly on delayed memory and executive function (2). The term cognitive covers brain function aspects related to various domains, for instance, attention, language, memory, learning, reasoning, decision making, and problemsolving. The involvement of cognitive and dementia is usually seen in patients with chronic kidney disease, especially in advanced stages (3). This study aimed to determine the correlation between the severity of chronic kidney disease and cognitive function.

\section{METHODS}

This study was a descriptive-analytic study with a crosssectional data collection method. The research subjects were taken from the CKD patient population at Haji Adam Malik Central General Hospital (HAM CGH). The inclusion criteria were patients in stage 3 to stage 5 CKD, compos mentis consciousness and cooperative, able to speak Indonesian, literate, and agree to participate in the research. The CKD degrees were determined by the Cockroft-Gault formula at HAM Central General Hospital. A total of 45 patients were selected using a consecutive non-random sampling method. The cognitive function was determined through the Montreal Cognitive Assessment (MoCA INA) with a total score of 30, MoCA INA is abnormal if the score $<26$, digit span for attention domain with a normal value if you can repeat 5-7 digits on the forward digit span examination and repeat 4 numbers on the backward digit span, and Trail Making Test (TMT) A \& B for executive domain with a maximum value of 180 seconds for TMT A and a maximum of 300 seconds for TMT B. Data were analyzed using the Spearman test. Additionally, a chi-square test was performed to see the role of CKD risk factors (hypertension, diabetes mellitus, kidney stones, glomerulonephritis) on cognitive function.

\section{RESULTS}

Of all chronic kidney disease patients in the Nephrology Subdivision, Internal Medicine Outpatient Clinic at Haji Adam Malik General Hospital Medan in the period of August 2018 - January 2019, 45 CKD patients met the inclusion criteria. The majority of subjects were male $(62.2 \%)$ with a mean age of $49.67 \pm 12.18$ years with the largest age group of $51-60$ years (37.8\%). Most of the respondents had a high school education level (57.8\%), came from the Batak ethnic group (55.6\%), and worked as employees or housewives (Table 1).

Table 1 also shows the clinical characteristics of subjects who have suffered from chronic kidney disease for $36.09 \pm 34.9$ months with a mean creatinine level of $8.74 \pm 5.7 \mathrm{mg} / \mathrm{dL}$ and an average glomerular filtration rate of $19.86 \pm 17.96 \mathrm{~mL} / \mathrm{min} / 1.73 \mathrm{~m}^{2}$. A number of 23 people (51.1\%) had the highest estimated glomerular filtration rate (eGFR) $<15 \mathrm{~mL} / \mathrm{min} / 1.73 \mathrm{~m} 2$ (stage 5 ). The results indicated that the possible causes of CKD were hypertension (46.7\%) and kidney stones (22.2\%) based on previous medical history.
Table 1. Descriptions of demographic characteristics of research subjects

\begin{tabular}{|c|c|c|}
\hline Demographic characteristics & $n=45$ & $\%$ \\
\hline Age (years), mean \pm SD & $49.67 \pm 12.18$ & \\
\hline \multicolumn{3}{|l|}{ Age Group n (\%) } \\
\hline $21-30$ years & 5 & $11.1 \%$ \\
\hline $31-40$ years & 7 & $15.6 \%$ \\
\hline $41-50$ years & 9 & $20.0 \%$ \\
\hline $51-60$ years & 17 & $37.8 \%$ \\
\hline $61-70$ years & 7 & $15.6 \%$ \\
\hline \multicolumn{3}{|l|}{ Gender $\mathrm{n}(\%)$} \\
\hline Male & 28 & $62.2 \%$ \\
\hline Female & 17 & $37.8 \%$ \\
\hline \multicolumn{3}{|l|}{ Ethnic Group n (\%) } \\
\hline Batak & 25 & $55.6 \%$ \\
\hline Javanese & 9 & $20 \%$ \\
\hline Karo & 8 & $17.8 \%$ \\
\hline Malay & 1 & $2.2 \%$ \\
\hline Chinese & 1 & $2.2 \%$ \\
\hline Indian & 1 & $2.2 \%$ \\
\hline \multicolumn{3}{|l|}{ Education n (\%) } \\
\hline Junior High School & 5 & $11.1 \%$ \\
\hline Senior High School & 26 & $57.8 \%$ \\
\hline College & 14 & $31.1 \%$ \\
\hline \multicolumn{3}{|l|}{ Occupation n (\%) } \\
\hline Employees & 12 & $26.7 \%$ \\
\hline Entrepreneurs & 9 & $20 \%$ \\
\hline Farmers & 9 & $20 \%$ \\
\hline Housewives & 10 & $22.2 \%$ \\
\hline Retired & 4 & $8.4 \%$ \\
\hline Do not work & 1 & $2.2 \%$ \\
\hline \multicolumn{3}{|l|}{ Past medical record n (\%) } \\
\hline Kidney stones & 10 & $22.2 \%$ \\
\hline Hypertension & 21 & $46.7 \%$ \\
\hline Diabetes Mellitus & 2 & $4.4 \%$ \\
\hline DM and Kidney Stones & 3 & $6.7 \%$ \\
\hline DM and Hypertension & 8 & $17.8 \%$ \\
\hline Acute Glomerulonephritis & 1 & $2.2 \%$ \\
\hline \multicolumn{3}{|l|}{ Estimated Glomerulus Filtration Rate } \\
\hline $\mathrm{mL} / \mathrm{min} / 1,73 \mathrm{~m} 2 \%$ & 10 & $22.2 \%$ \\
\hline 30-59 (stage 3 CKD) & 12 & $26.7 \%$ \\
\hline $15-29$ (stage 4 CKD) & 23 & $51.1 \%$ \\
\hline$<15$ (stage 5 CKD) & $36.09 \pm 34.9$ & \\
\hline \multirow{2}{*}{$\begin{array}{l}\text { Duration of suffering from CKD (months), } \\
\text { mean } \pm S D\end{array}$} & $8.74 \pm 5.70$ & \\
\hline & $19.86 \pm 17.96$ & \\
\hline \multicolumn{3}{|l|}{ Creatinine level $(\mathrm{mg} / \mathrm{dL})$ mean $\pm \mathrm{SD}$} \\
\hline $\mathrm{GFR}\left(\mathrm{mL} / \mathrm{min} / 1,73 \mathrm{~m}^{2}\right)$ mean $\pm \mathrm{SD}$ & & \\
\hline
\end{tabular}

Note: DM: Diabetes Mellitus, CKD: Chronic Kidney Disease, GFR: glomerular filtration rate

Of all CKD patients who had cognitive function checked (Table 2), the mean MoCA INA score was 22.97 \pm 4.56 , FDS 4.28 \pm 1.3 , BDS $2.84 \pm 0.6$, TMT A time $139.7 \pm 37.8$ seconds, TMT A error $2.18 \pm 3.12$, TMT B time $231.7 \pm 77.3$ seconds, and TMT B error 9.49 \pm 6.52 .

Table 2. Characteristics of cognitive function

\begin{tabular}{lr}
\hline Cognitive Function & \multicolumn{1}{c}{ Mean \pm SD } \\
\hline MoCA Score & $22.97 \pm 4.56$ \\
FDS Score & $4.28 \pm 1.3$ \\
BDS Score & $2.84 \pm 0.6$ \\
TMT A & \\
Time (seconds) & $137.47 \pm 34.69$ \\
Error & $2.18 \pm 3.12$ \\
TMT B & \\
Time (seconds) & $225.49 \pm 57.30$ \\
Error & $9.49 \pm 6.52$ \\
\hline
\end{tabular}

Note: MoCA: Montreal Cognitive Assessment, FDS: Forward digit span, BDS: Backwarddigit span, TMT A: Trail Making Test A, TMT B: TMT A: Trail Making Test A 
In this study, there were no significant differences in CKD risk factors for cognitive functions (Table 3). The risk factors explored included hypertension, diabetes mellitus, kidney stones, and glomerulonephritis.

Table 3. The relationship between CKD risk factor and cognitive function

\begin{tabular}{lrrr}
\hline Risk Factor & Cognitive Function & P \\
\hline HT & Normal & Abnormal & \\
Yes & 9 & 20 & 0.452 \\
No & 6 & 10 & \\
DM & & & \\
Yes & 5 & 8 & 0.447 \\
No & 10 & 22 & \\
Kidney stones & & & \\
Yes & 4 & 9 & 0.553 \\
No & 19 & 21 & \\
Glomerulonephritis & & & \\
Yes & 1 & 0 & 0.333 \\
No & 11 & 21 & \\
\hline Note: Chi-square test & & &
\end{tabular}

Table 4 illustrates a significant positive correlation between the CKD stages and the MoCA-INA ( $p=<0.001$, $r=0.618)$ and FDS $(p=0.005 r=0.414)$. The TMT examination found a significant negative correlation between the CKD stages with TMT A time $(r=-0.425$, $p=0.004)$, TMT A error $(r=-0.497, p=0.001)$, TMT $B$ time $(r=-0.618, p=<0.001)$, and TMT B error $(r=-0.370$, $\mathrm{p}=0.012$ ).

Table 4. Correlation between GFR values and cognitive function

\begin{tabular}{crcccccc}
\hline \multirow{2}{*}{$\begin{array}{c}\text { LFG } \\
\text { Value }\end{array}$} & $\begin{array}{c}\text { MoCA- } \\
\text { INA }\end{array}$ & FBSS & D & $\begin{array}{c}\text { TMT A } \\
\text { time }\end{array}$ & $\begin{array}{c}\text { TMT A } \\
\text { error }\end{array}$ & $\begin{array}{c}\text { TMT B } \\
\text { Time }\end{array}$ & $\begin{array}{c}\text { TMT B } \\
\text { error }\end{array}$ \\
\hline $\mathrm{r}$ & 0.618 & 0.414 & 0.132 & -0.425 & -0.497 & -0.618 & -0.370 \\
$\mathrm{p}$ & $<0.001$ & 0.005 & 0.388 & 0.004 & 0.001 & $<0.001$ & 0.012 \\
\hline
\end{tabular}

Note: Spearman test

\section{DISCUSSION}

This study found that most of the CKD patients were men with the largest age group of 50-60 years. The results also showed that the severity of CKD was directly proportional to cognitive function. The dominance of male patients with CKD is in line with previous studies that found men were more often diagnosed with chronic kidney disease than women $(4,5)$.

Sex hormones that play a role in the development of CKD tend to be slower in women. Gender influences agerelated changes in the renin-angiotensin system (RAS) and nitric oxide (NO), as well as metalloprotease activity. The role of gender in the renin-angiotensin system is related to the interaction between 17 $\beta$-estradiol (E2) and Angiotensin II. E2 reduces tissue levels and activity of angiotensin II and angiotensin-converting enzyme (ACE). On the contrary, testosterone tends to increase RAS activity. Parallel to the increasing age, endothelial NO synthase (eNOS) production decreases, and oxidative stress increases thus leads to endothelial dysfunction. The gender differences may be related to the relationship between NO and E2, which stimulates the release of NO synthase. Increased age is related to delayed asymmetric dimethyl $L$ arginine in perimenopause women than men, which can result in more NO synthesis. The effect of renal vasoconstriction on the inhibition of NO synthesis is more noticeable among adult males than in females (6).

The description of the age of the subjects in this study (5060 years) is in line with the study conducted by Aisarah et al., and Tamura et al., they found that the most age range of CKD patients was 40-60 years with a mean age of 51.6 \pm 13.3 . Decreased kidney function is a normal process as the age increases. Increasing age indicates a progressive decrease in the glomerular filtration rate (GFR) and renal blood flow. The decline occurred approximately 8 $\mathrm{ml} / \mathrm{minute} / 1.73 \mathrm{~m}^{2}$ per decade started from the age of 40 years $(4,6,7)$.

This study found a significant positive correlation between MoCA-INA score and cognitive function. This is in line with previous studies which found that CKD patients with eGFR $<60 \mathrm{ml} /$ minute $/ 1.73 \mathrm{~m}^{2}$ had poor cognitive function $(p=<0.001)$, and the mean FDS was $4.69 \pm 0.94$ with $p$ value $=0.012(3,8)$. Patients with kidney disease are more likely to have large and small blood vessel disease, which causes problems with white matter and reduces white matter integrity, which is associated with cognitive impairment and is common in superimposed neurodegenerative disease. This vascular disease will increase the incidence of cerebrovascular disease associated with subclinical microvascular cerebral disease and stroke. Patients with CKD tend to be at risk for cognitive impairment caused by associated vascular disease, known as cerebral microinfarcts and white matter disease, and not Alzheimer's disease (9).

The mechanism of cerebral small vessel disease in CKD patients involves the cumulative effect of several vascular risk factors. CKD patients experience decreased renal function and increased level of asymmetric nitric oxide synthase inhibitor dimethyl-L-deminine, which suppresses nitric oxide synthesis. Nitric oxide is an inhibitor of vascular smooth muscle cell proliferation, platelet aggregation, and a strong vasodilator. Endothelial dysfunction resulting from reduced production of nitric oxide in small cerebral vessels can contribute to the development of chronic ischemic damage to subcortical structures. Endothelial dysfunction is associated with white matter hyperintensity with decreased vasodilation capacity of the cerebral cortex (10).

In this study, there was a significant negative correlation on the examination of TMT A time, TMT A error, TMT B time, and TMT B error with different levels of correlation. The results are in line with previous studies that found a relationship between CKD severity and executive domain $(4,10)$. A clinically significant deficit that met the most common $\mathrm{MCl}$ criteria was found in the non-memory domain. Impaired executive function is associated with manifestations of cerebral small vessel disease, such as lesions on white matter. Subcortical white matter lesions are common in advanced CKD and are related to the severity of kidney disease (10).

The absence of a significant relationship with the risk factors for cognitive dysfunction could be caused by the 
limitation of subjects, specifically the patients who meet the inclusion criteria at HAM CGH, so it does not represent the true population. Besides, the diagnosis of stroke is only enforced based on anamnesis and physical examination without a head CT scan.

This study conclude a significant positive correlation between the severity of CKD and cognitive function based on the MoCA INA and FDS scores, and also a significant negative correlation between the severity of CKD and TMT

\section{REFERENCES}

1. Suwitra K. Penyakit Ginjal Kronik. In: Sudoyo AW (Ed). Buku Ajar Ilmu Penyakit Dalam. 6th edition. Jakarta: Interna Publishing; 2014; p. 2159-2165.

2. Richards TEF, Costa SA, Holschbach $\mathrm{B}$, et al. The Montreal Cognitive Assessment (Moca)- A Sensitive Screening Instrument for Detecting Cognitive Impairment in Chronic Hemodialysis Patients. PLoS One. $2014 ;$ 9(10): 1-9.

3. Iyasere $O$ and Brown EA. Cognitive Function Before and After Dialysis Initiation in Adults with Chronic Kidney Disease- a New Perspective On an Old Problem? Kidney international. 2017; 91(4): 784786.

4. Tamura KM, Yaffe $\mathrm{K}, \mathrm{Hsu} \mathrm{CY}$, et al. Cognitive Impairment and Progression of CKD. American Journal of Kidney Diseases. 2016; 68(1); 77-83.

5. Susianti NA, Astuti, Asmedi A, Gofir A, and Djarwoto B. Profil Fungsi Kognitif Pasien Gagal Ginjal Kronik yang Menjalani Hemodialysis. Neurona. 2015; 32(4): 1-7.
A time, TMT A error, TMT B time, and TMT B error.

\section{ACKNOWLEDGEMENT}

The researchers would like to thank the Faculty of Medicine, Universitas Sumatera Utara, the Department of Neurology and Diseases in the Nephrology Subdivision and Haji Adam Malik Central General Hospital Medan that have facilitated this research.

6. Wenstein JR and Anderson S. The Aging Kidney: Physiological Changes. Advances in Chronic Kidney Disease. 2010; 17(4): 302-307.

7. Aisara S, Azmi S, and Yanni M. Gambaran Klinis Penderita Penyakit Ginjal Kronik yang Menjalani Hemodialisis di RSUP Dr. M. Djamil Padang. Jurnal Kesehatan Andalas. 2018; 7(1): 42-50.

8. Paraizo MA, Almeida ALM, Pires LA, et al. Montreal Cognitive Assessment (Moca) Screening Mild Cognitive Impairment in Patients with Chronic Kidney Disease (CKD) Pre-Dialysis. The Brazilian Journal of Nephrology. 2016; 38(1):31-41.

9. Bronas $\mathrm{GU}$, Puzantian $\mathrm{H}$, and Hannan M. Cognitive Impairment in Chronic Kidney Disease: Vascular Milieu and the Potential Therapeutic Role of Exercise. BioMed Research International. 2017; 2017: 1-10.

10. Belbessi ASE, Gohary IEE, Sheshtawi HA, and Mohamed MMA. Cognitive Disorders in Chronic Kidney Disease and Hemodialysis Patients. Journal of The Egyptian Society of Nephrology and Transplantation. 2018; 18(4): 130-136. 